\title{
The use of mathematical models for the regulation of hydrogenerator voltage control
}

\author{
Fedor Shkrabets ${ }^{1}$, \\ Vitalij Radchenko ${ }^{2}$ \\ ${ }^{1}$ Dnipro University of Technology, \\ Dmytra Yavornytskoho Ave. 19, \\ 49005, Dnipro, Ukraine \\ Email: shcrabetsf@nmu.org.ua \\ ${ }^{2}$ Zaporizhia State Engineering Academy, \\ Soborniy Ave. 226, \\ 61 000, Zaporizhia, Ukraine \\ Email:radchvv@ukr.net
}

\begin{abstract}
The problem of increasing the efficiency level of hydrogenerator voltage control with regard to its systemic role - the mobile power reserve of the energy system - is considered. An analysis of existing technical solutions of circuits with self-excitation of the hydrogenerator shows the presence of unavoidable time constants of feedback circuits, significantly reducing the dynamic efficiency of voltage control systems. The development of solutions that eliminate the inertia of feedback increases the stability and dynamic efficiency of the main equipment of hydropower stations.
\end{abstract}

Keywords: model, information, semantics, inertia, efficiency

\section{INTRODUCTION}

The problem of the functional efficiency of the initial power transformers HES $[1,2]$ is of major importance basing on significant restrictions of modern power engineering.

The modelling of hydroaggregate regulators - the main power unit on the hydroelectric station - is of great practical importance, since their characteristics and power structures influence the functional power efficiency.

Conceptual development of models is very important because it allows to create the desired content part and the required functional content [3-5] according to system conditions and constraints. The hydroaggregate has a voltage regulator (VR) of the excitation system (ES) in the feedback circuit. Therefore, the influence of the VR characteristics on the hydroaggregate dynamic efficiency is decisive [6,7]. To increase the dynamic working component, a clock method of non-inertial voltage regulation has been developed $[8,9]$.
Inertia characteristics of the hydrogenerator and the excitation system significantly affect the duration and quality of the transient process of the voltage regulation system.

The development of theoretical basis, semantic models of a fast, non-inertial algorithm of measurement and transformation of variable signals for regulators of the hydrogenerator excitation system was carried out. The formation of components of the hydrogenerator excitation control is based on the developed technology of isolating and processing the semantic components of the controlled process, as well as their metrological support.

The semantic models of transformation of signals [10] of the hydrogenerator excitation system, the synchronous generator (SG) are developed. The evaluation and organization of energy information influences within the current exchange for the implementation of main functional processes in the primary converters of hydropower systems allows to provide the necessary efficiency level, including the dynamic one. 
Reducing the order of a closed excitation regulation system provided that sufficient speed and level of forcing non-inertial regulators is provided, develops the properties of strong action, increases the stability and dynamical efficiency of energy converters, reducing the duration and loss of transient hydroaggregates and increases generation efficiency.

\section{MATHEMATICAL MODELS}

\section{Mathematical model of voltage control signal}

The development of the mathematical model of the dynamic control method is based on the following provisions. The basis of its action is to form a controlling influence proportional to the semantics of controlled voltage. The proposed model solves the problem of forming the output signal of the regulator, Fig. 1. In this model, the amplitude value of the voltage varies within $\left[A_{0}, Y_{2}\right]$ with a step:

$$
\mathrm{A} 1=\frac{A_{0}-Y_{2}}{10} .
$$

The ratio to the area of the half-period $S$ :

$$
k=S_{1} / S \text {. }
$$

The system of difference coordinates was introduced, of which C3 and C5 belong to the SC area, and $\mathrm{C} 4$ is the domain of the SR. The area of the sinusoidal part of the signal is determined by the ratio:

$$
S_{C}=A\left(1-\cos x_{1}\right) .
$$

The area of rectangular part is determined by equality:

$$
S_{\Pi}=2 Y_{1}\left(\pi / 2-x_{1}\right) .
$$

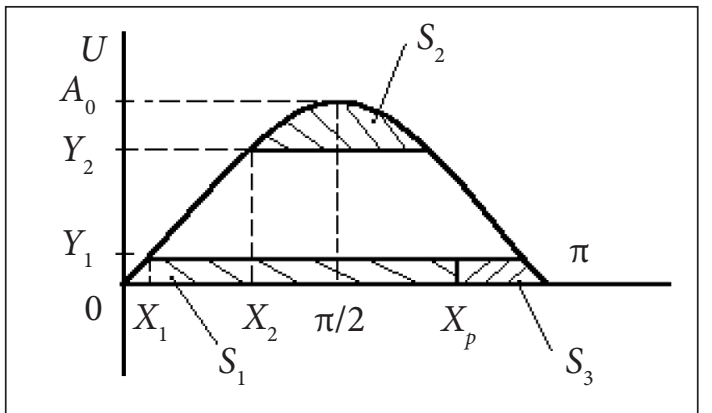

Fig. 1. Forming of voltage control signal
The compared areas are calculated by formulas:

$$
\begin{aligned}
& S_{1}=S_{\Pi}+2 S_{C^{\prime}} \\
& S_{2}=2 A\left[\cos x_{2}-\sin x_{2}\left(\pi / 2-x_{2}\right)\right] .
\end{aligned}
$$

The signal proportional to the deviation is determined by the ratio:

$$
S_{3}=S_{1}-S_{2} \text {. }
$$

As the voltage in the calculation process varies, for each value of $A$, new coordinates of the levels of constraints are determined as:

$$
\begin{aligned}
& x_{1}=\operatorname{Arcsin}\left(Y_{1} / A\right), \\
& x_{2}=\operatorname{Arcsin}\left(Y_{2} / A\right),
\end{aligned}
$$

To increase the accuracy, difference coordinates of the control angles are determined out of the following conditions:

$$
\begin{aligned}
& \text { 1. If } S_{3} \leq S_{C^{\prime}} \\
& C_{3}=\operatorname{Arccos}\left(1-S_{3} / A\right) ; C_{4}=0 ; C_{5}=0 . \\
& \text { 2. If } S_{3} \leq S_{1}-S_{C^{\prime}} \\
& C_{3}=x_{1} ; C_{4}=\left(S_{3}-S_{C}\right) / y_{1} ; C_{5}=0 . \\
& \text { 3. If } S_{3}>S_{1}-S_{C^{\prime}} \\
& C_{3}+C_{4}=\pi-x_{1} ; \\
& C_{5}=\operatorname{Arccos}\left[S_{3}-\left(S_{C}+S_{\Pi}\right)\right] / A-1 .
\end{aligned}
$$

Then a control angle makes:

$\varphi=C_{3}+C_{4}+C_{5}$.

From there, the inclusion angle of a thyristor or transistor is:

$\alpha=\pi-\varphi$

The average value of the generated voltage is:

$$
U_{C}=\frac{A}{\pi}(1-\cos \alpha) .
$$


The current value of the regulated voltage is:

$$
U_{d}=A \sqrt{1 / 2-\alpha / 2 \pi+\sin 2 \alpha / 4 \pi} .
$$

According to the results of the modelling, the dependences $\varphi=f(A), \alpha=f(A)$ and $S_{2}=f(A)$, Fig. 2, rice. 3?? are obtained, which are the characteristics of the separating semantics method, as well as a number of characteristics of RN: $U_{C}=f(A), U_{d}=f(A), U_{C}=f(\alpha), U_{d}=f(\alpha)$, Figs. 4, 5. An analysis of the obtained characteristics suggests that as $k$ increases, the informativity and the ratio decrease and the nonlinearity of the output signal characteristics increases.

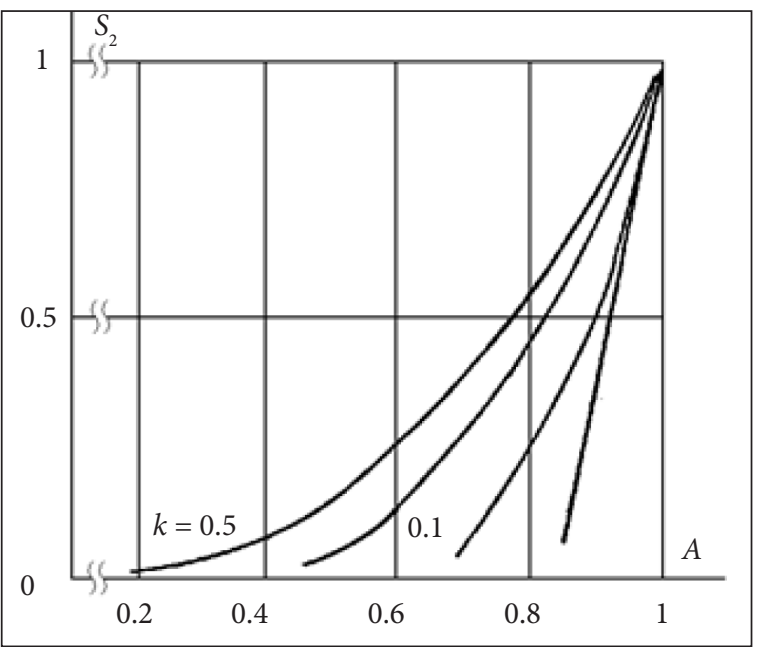

Fig. 2. Characteristics of informative area

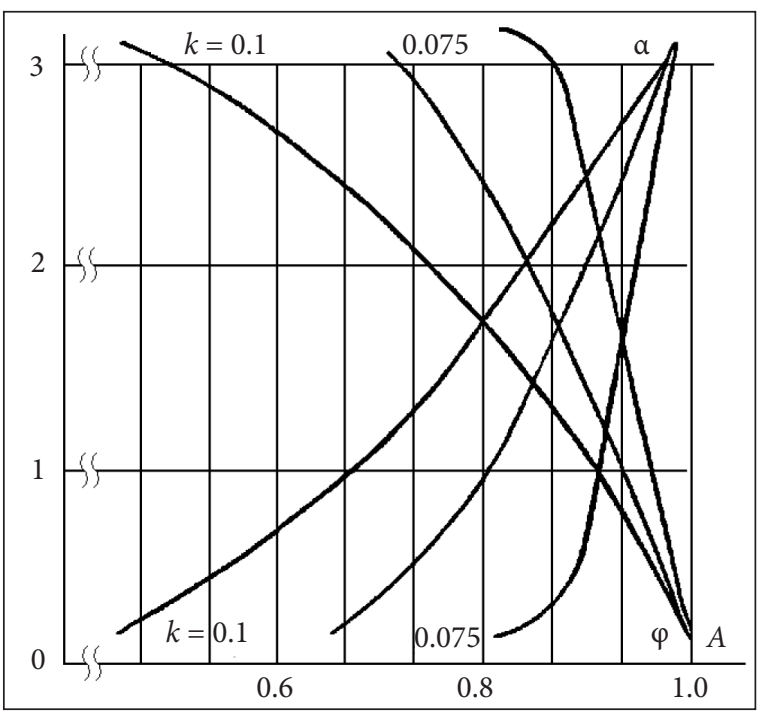

Fig. 3. Characteristics of transformation method

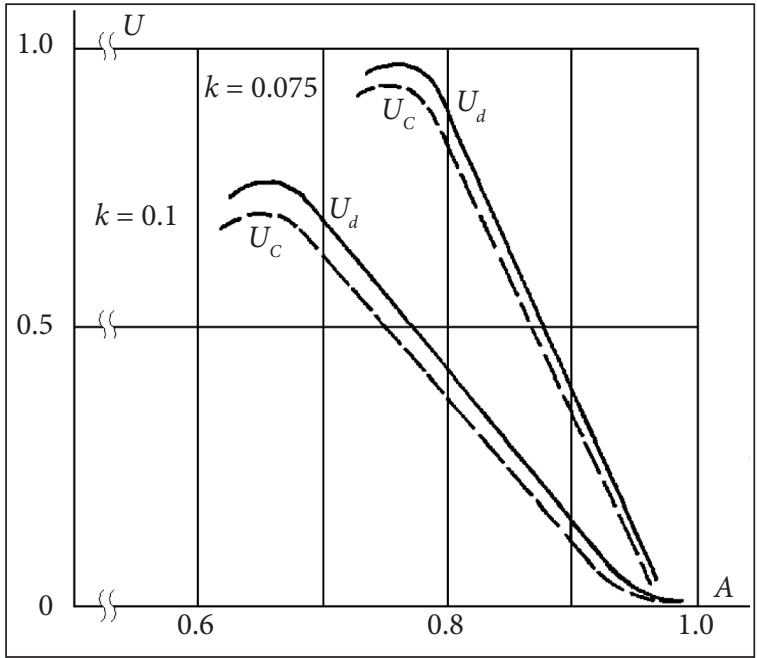

Fig. 4. Characteristics of control

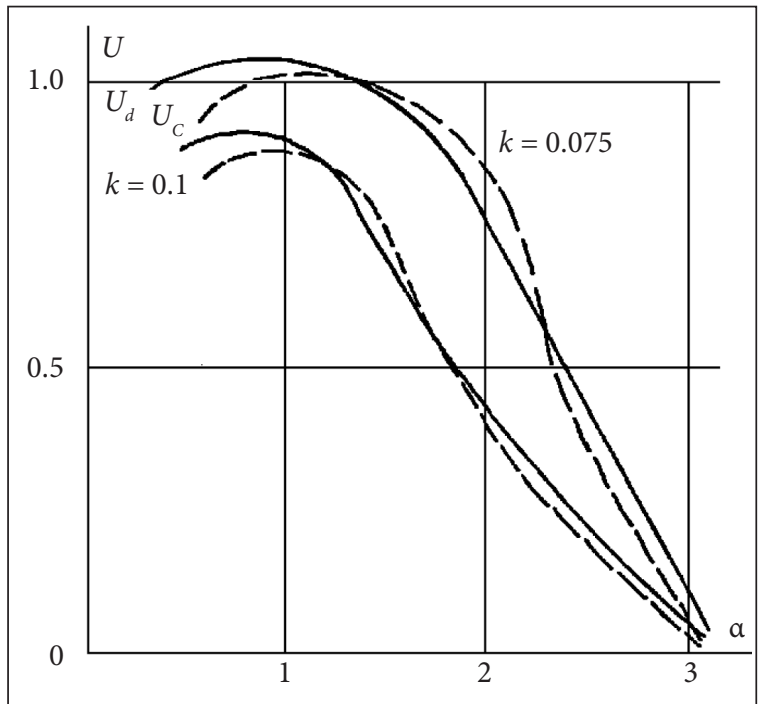

Fig. 5. Characteristics of excitation control

These characteristics, having a rather high slope of the active control area, reflect a significant energy-information potential of the regulators, which is directly dependent on the settings of the primary converter, according to the adjustment model.

\section{FEATURES OF MATHEMATICAL MODEL OF THREE-PHASE VC (VOLTAGE CONTROL)}

Depending on the implementation of the controlled rectifier according to one of the threephase circuits [11-12], output signal VC may contain three ripples over a period (threephase zero circuit or semi-controlled rectifying 
circuit), or six ripples (controlled bridge circuit). However, the formation of a control signal with an appropriate shift through the control channels is practically the same. Therefore, adequate consideration is given to the formation of a control signal per channel, Fig. 6. On the model, the duty cycle corresponding to the level $y_{1}$ is combined with the corresponding half-life of the working cycle. Conditional assumptions, practically without affecting the adequacy, greatly simplify the correlation of the model.

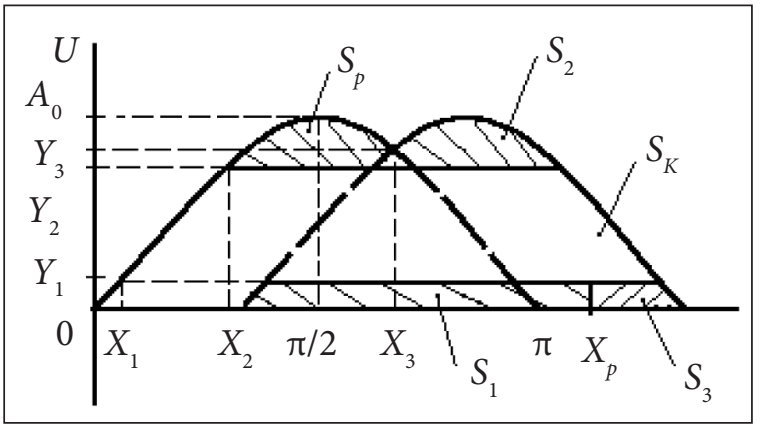

Fig. 6. Combination of working cycles when determining levels

The feature of this model is the necessity to determine the coordinates of phase change $\left(x_{3}\right.$, $y_{3}$ ) and the beginning of the regulatory half-period. As can be seen from the above, the range of control when changing the amplitude value of the voltage from $A$ to $A_{1}$ is $180^{\circ}$ and partially covers the second pulsation of the rectified voltage. In determining the regulation angle, the origin of the coordinates is shifted to 0 . In the calculation process, the amplitude value of the voltage $\mathrm{A}$ varies within $\left(A_{0}, y_{2}\right)$ with a given or calculated step.

The area of the half-period of the sinusoidal signal is:

$$
S=2 A .
$$

The operating conditions:

$$
S_{2}=k S \text {. }
$$

The area of the second tact is calculated by the formula:

$$
S_{1}=2 S_{C}+S_{\Pi}
$$

The constituents are determined by formulas:

$$
\begin{aligned}
& S_{C}=A\left(1-\cos x_{1}\right) ; \\
& S_{\Pi}=2 y_{1}\left(\pi / 2-x_{1}\right) .
\end{aligned}
$$
nal:

The area is proportional to the deviation sig-

$$
S_{3}=S_{1}-S_{2}
$$

Since the amplitude of voltage changes, it is necessary to calculate the coordinates of restriction levels at every step:

$$
\begin{aligned}
& x_{1}=\operatorname{Arcsin}\left(y_{1} / A\right), \\
& x_{2}=\operatorname{Arcsin}\left(y_{2} / A\right) .
\end{aligned}
$$

When calculating the regulation angle, the corresponding difference coordinates are determined $-C_{3}, C_{4}, C_{5}$. In this case, $C_{3}$ and $C_{5}$ are within the limits of the inverse $S S$, and $C_{4}$ within the limits of the $S_{\Pi}$. To increase the accuracy of the model, the following intervals are allocated:

$$
\begin{aligned}
& \text { 1. At } S_{3} \leq S_{C} \\
& C_{3}=\operatorname{Arccos}\left(1-S_{3} / A\right) ; C_{4}=0 ; C_{5}=0 .
\end{aligned}
$$

2. At $S_{3} \leq S_{1}-S_{C}$

$$
C_{3}=x_{1} ; C_{4}=\frac{S_{3}-S_{C}}{y_{1}} C_{5}=0 \text {. }
$$

3. At $S_{3}>S_{1}-S_{C}$

$$
\left(C_{3}+C_{4}=\pi-x_{1} ; C_{5}=\operatorname{Arccos} \frac{S_{3}-\left(S_{C}+S_{I I}\right)}{A}-1\right) .
$$

Thus, the operating components of the coordinates of the control angle are determined.

The angle of a switched regulator is:

$$
\varphi=C_{3}+C_{4}+C_{5} .
$$

The angle of inclusion is:

$$
\alpha=\pi-\varphi
$$

The mean and current values of the excitation voltage are calculated by the known formulas, 
depending on the used rectifying scheme. As a result of the modelling, the dependences $S_{2}=f(A)$, $\varphi=f(\mathrm{~A}), \alpha=f(A)$, Figs. 7, 8, as well as $U_{C}=f(\alpha)$, $U_{d}=f(\alpha), U_{C}=f(A), U_{d}=f(A)$, Figs. 9, 10.

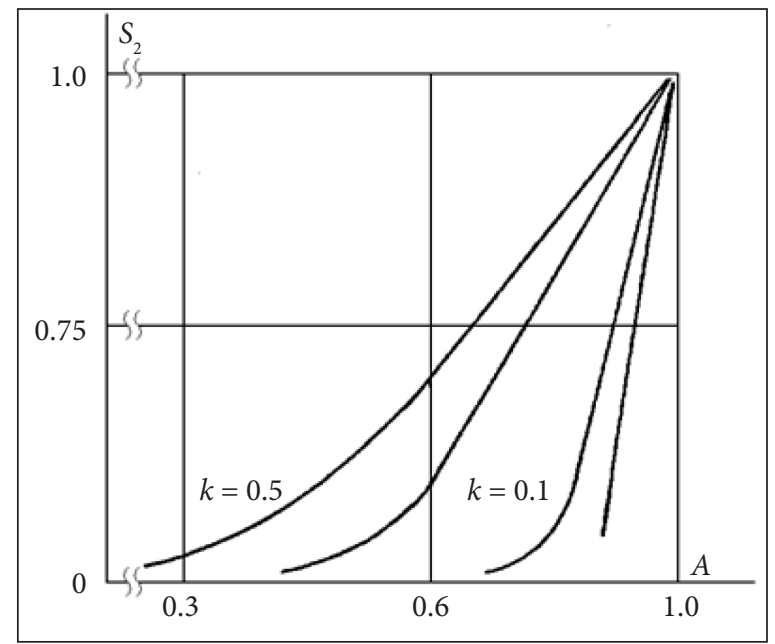

Fig. 7. Characteristics of the informative area

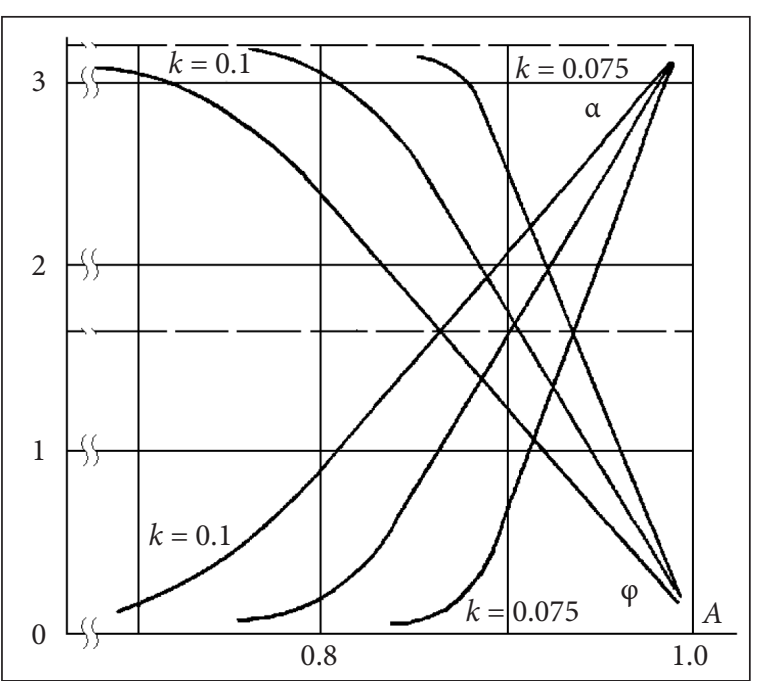

Fig. 8. Characteristics of the transformation method

The above characteristics reflect high steepness and linearity of the working area of the resulting energy information exchange. They allow you to dynamically implement the required level of quality of the excitation control signal and thus affect the efficiency of the managed system.

The above characteristics of the three-phase VC reflect a significant energy-information excitation potential, rather high steepness of the active regulatory area, as well as a significant potential for controllers to move, depend-

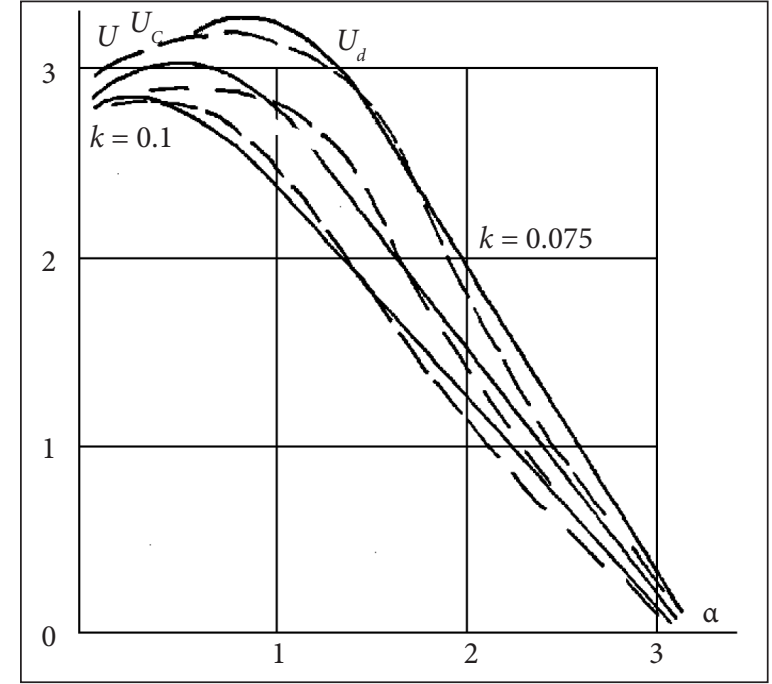

Fig. 9. Characteristics of three-phase regulato

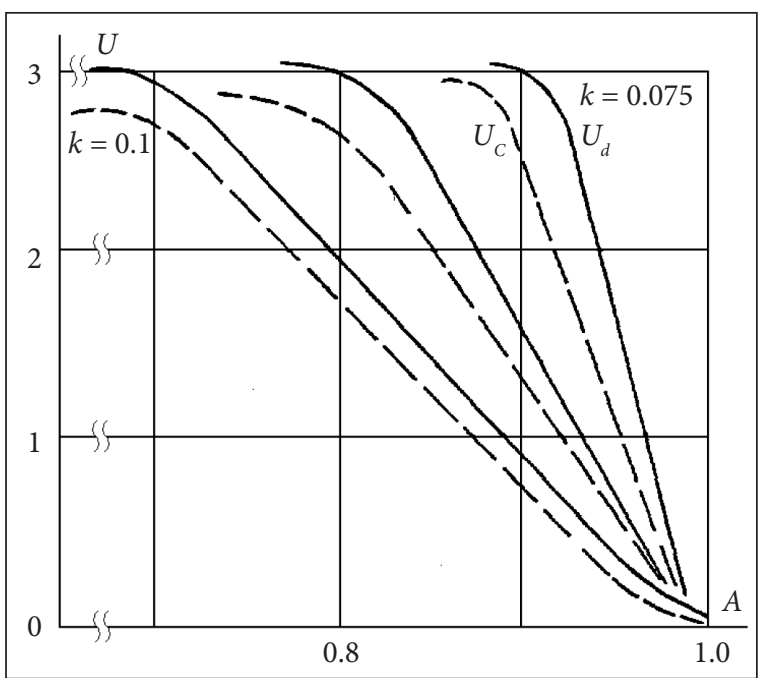

Fig. 10. Characteristics of excitation regulation

ing on the debugging of the primary converter. Combined with the speed and lack of inertia, the forcing power provides new dynamic control qualities.

\section{NUMERICAL ANALYSIS}

The analysis of the obtained characteristics shows that in the case of three-phase implementation of the measurement method, the part of the linear section of the characteristics is slightly increased and the corresponding value of the rectified voltage at the output of the regulator, which provides a significant level of influence, increases. 
Equally important are the informational content capabilities of the developed methods and measuring transducers of the alternating voltage on their basis, Fig. 11:

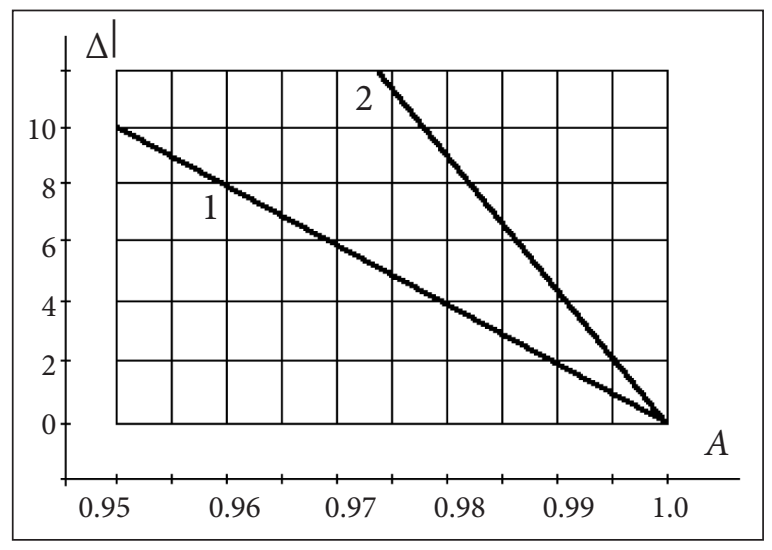

Fig. 11. Information characteristics of the converters: 1 - singlephase version; 2 - three-phase version

An analysis of mathematical relations of the model also shows periodic functions of the same character for each operating cycle which also provides a new quality. Thus, change in the frequency of controlled voltage results in a proportional change areas $S_{1}$ and $S_{2}$, as well as $S_{3}$, which provides the consistency of the prevailing angle $\alpha$ change.

Thus, the full frequency invariance of the developed method [13] is realized, which is also an important functional quality. The developed solutions are verified theoretically at the mathematical level and practically in the composition of physical models of the excitation systems [14].

The external characteristic of VC has the form presented in Fig. 12:

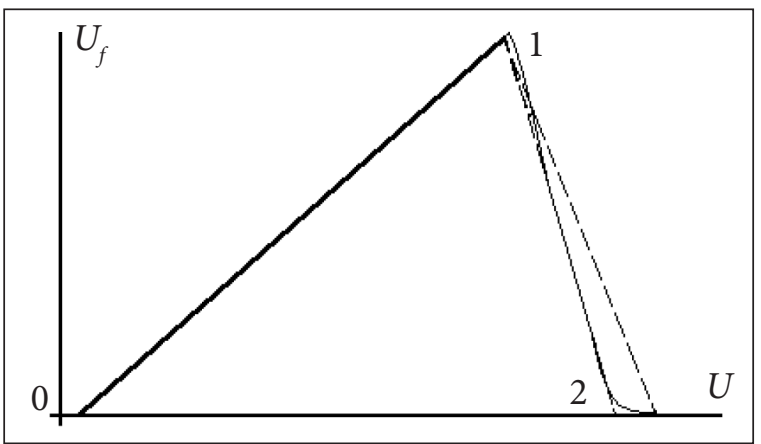

Fig. 12. External characteristic of VC: 1 - theoretical (dotted); 2 - practical
It should be noted that the external characteristic of VC sufficiently corresponds to the theoretical control law. Some non-linearity of the active site of the characteristic practically does not affect the quality of excitation control.

The steepness of the active control area 1 to 2 , in combination with the speed and lack of inertia, allows to implement the function equivalent to strong excitation control without using inertial excitation control. This approach avoids inertia $[6,7]$ and overregulation and, accordingly, oscillations in the transient process of restoring the hydroaggregate voltage, Fig. 13.

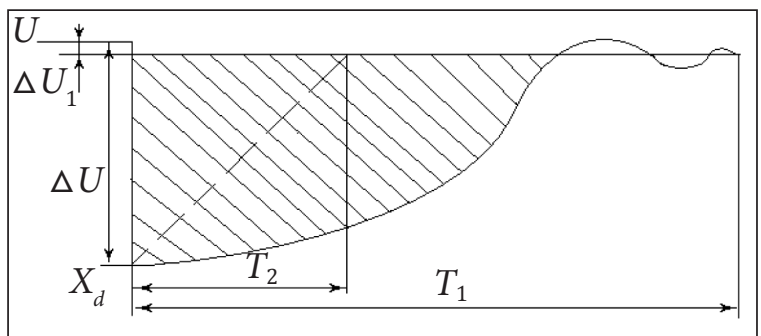

Fig. 13. Characteristic of voltage restoration: $T_{1}$ - time of recovery in inertial ES; $T_{2}$ - absence of inertia of ES

The determined characteristics and the obtained parameters of the transition process convincingly prove a significant reduction in the dynamic losses of the transition process due to its optimal implementation, which is mainly achieved by the lack of inertia and a sufficient level of energy exchange of the excitation cycle of the hydroaggregate $[15,16]$.

\section{CONCLUSIONS}

1. The conceptual model basis of providing necessary qualities and efficiency of hydroaggregate excitation control is developed. The basic restraints and functionally important conditions necessary to achieve the expected results are shown.

2. The specified conditions and peculiarities of the manifestation and realization of separate components on the background of their main system purpose are pointed out.

3. Semantic models of an effective non-inertial transformation method of variable signals of the voltage control of the aggregate excitation system are developed. 
4. Models of effective regulation of voltage and non-inertial excitation are developed, which allow to substantially increase the working quality of generation, including dynamic hydroaggregates.

5. The obtained characteristics of aggregate voltage regulators correspond to analytical dependencies and provide the quality of strong control on a non-inertial basis.

Received 21 October 2018 Accepted 27 November 2018

\section{References}

1. Anderson P. M., Fouad A. A. Power System Control and Stability. Wiley-IEEE Press, 2002. 678 p.

2. Pojuev V. I., Radchenko V. V., Skrabets F. P., Kucher V. G., Kobets V. A. Definition of efficiency of existing hydropower systems. Electrical Engineering and Power Engineering. 2013. No. 2. P. 71-76.

3. Kogan I. M. Applied Information Theory. M.: Radio i svyaz. 1981. 216 p. (in Russian).

4. Beus H. L. The use of information in sorting. Journal of ACM. 1970. Vol. 17. No. 3.

5. Dandeno P. L., Hauth R. L., Schulz R. Effects of synchronous machine modeling in large scale system stability. IEEE Transactions. 1973. Vol. PAS92. No. 2. P. 574-582.

6. Radchenko V. V. Influencing to inertia of the system of excitation on dynamic qualities of hydrogenerator. STC Mining Electromechanics and Automation. 2013. No. 90. P. 119-125 (in Ukrainian).

7. Radchenko V. V. Forcing excitation and dynamic transitional process of hydrogenerator. STC Mining Electromechanics and Automation. 2014. No. 92. P. 83-90 (in Ukrainian).

8. MKI G01 R 19/22, Pat. Ukraine. 2012. No. 68900. 10. 04 .

9. Radchenko V. V. Not inertia measuring rejections of variable processes. STC Mining Electromechanics and Automation. 2013. No. 91. P. 73-78 (in Ukrainian).

10. Radchenko V. V. Semantic model of transformation of variable signal. STC Mining Electromechanics and Automation. 2017. No. 98. P. 57-59 (in Ukrainian).
11. Chaki F., Herman I., Ipshich I. et al. Power Electronics. M.: Energoizdat, 1982. 384 p. (in Russian).

12. Energy Electronics (ed. V. A. Labuntsova). M.: Energoatomizdat, 1987. 464 p. (in Russian).

13. Petrov B. N., Victorov V. A., Lunkin B. V., et al. Principle to the Invariance in Measuring Technique. M.: Nauka, 1976. 243 p. (in Russian).

14. Radchenko V. V. Processes in the Systems of Excitation of Hydrogenerators. Monograph. Zaporozhia: ZDIA, 2012. 248 p. (in Ukrainian).

15. Filippova T. A. Optimization Power Modes of Hydroaggregates of the Hydroelectric Power Stations. M.: Energiya. 1975. 207 p. (in Russian).

16. Radchenko V. V. Dynamic efficiency of the system of excitation of hydrogenerator. Announcer of NUVGP. Rivne. 2015. Vol. 2(62). P. 262-275 (in Ukrainian).

\section{Fedor Shkrabets, Vitalij Radčenko}

\section{MATEMATINIŲ MODELIŲ PANAUDOJIMAS REGULIUOJANT HIDROGENERATORIŲ ITAMPA}

\section{Santrauka}

Nagrinejama problema, susijusi su hidrogeneratoriaus ittampos valdymo efektyvumo padidinimu, atsižvelgiant $\mathfrak{i}$ jo sistemini vaidmenị - mobilųji energetikos sistemos galios rezervą. Esamų techninių sprendimų, susijusių su hidrogeneratoriaus savaiminiu sužadinimu, analizė rodo, kad egzistuoja neišvengiamos grịžtamojo ryšio grandinių laiko konstantos, sumažinančios įtampos valdymo sistemų dinaminị efektyvumą. Sprendimų, pašalinančių grị̌žtamojo ryšio inerciją, kūrimas didina hidroelektrinių pagrindinès įrangos stabilumą ir dinaminị efektyvumą.

Raktažodžiai: modelis, informacija, semantika, inercija, efektyvumas 